ఠ

\title{
Efficacy of sorafenib after liver transplantation in patients with primary hepatic carcinoma exceeding the Milan criteria: a preliminary study [Corrigendum]
}

\author{
Huang L, Li GM, Zhu JY, Li Z, Li T, Leng XS. OncoTargets \\ and Therapy 2012, 5:457-462.
}

Paper listed as a "Review" in error, should have been listed as "Original Research". journal focusing on the pathological basis of all cancers, potential targets for therapy and treatment protocols employed to improve the management of cancer patients. The journal also focuses on the impact of management programs and new therapeutic agents and protocols on

patient perspectives such as quality of life, adherence and satisfaction. The manuscript management system is completely online and includes a very quick and fair peer-review system, which is all easy to use. Visit http://www.dovepress.com/testimonials.php to read real quotes from published authors. 